\title{
Süleyman Demirel Üniversitesi Açık Yeşil Alan Ve Parklarının Personel Ve Öğrencilerin Yaşam Kalitesi Üzerine Etkileri
}

\author{
Ahmet TOLUNAY ${ }^{*}$, Alp KÜÇÜKCOŞKUN ${ }^{2}$, Türkay TÜRKOĞLU ${ }^{3}$, Mehmet ÖZMIŞ ${ }^{4}$ \\ ${ }^{1}$ Isparta Uygulamalı Bilimler Üniversitesi, Orman Fakültesi, Isparta, Türkiye \\ ${ }^{2}$ Süleyman Demirel Üniversitesi, Devlet Konservatuarı Isparta, Türkiye \\ ${ }^{3}$ Muğla Sitkı Koçman Üniversitesi, Köyceğiz Meslek Yüksek Okulu, Köyceğiz, Muğla \\ ${ }^{4}$ Isparta Uygulamalı Bilimler Üniversitesi, Lisansüstü Eğitim Enstitüsü, Isparta, Türkiye
}

\section{Öz}

Üniversite öğrenimi ve yerleşkesi öğrencilik yaşamında unutulmayan önemli anıları barındırmaktadır. Son yıllarda, öğrenciler tarafindan üniversite seçiminde, üniversite kampüslerinde bulunan sosyal yaşam alanları, parklar ve bahçeler önemli bir kıstas olarak yer almaya başlamıştır. Bu çalışmada Isparta Süleyman Demirel Üniversitesi'nin sahip olduğu parklar, meydanlar, çim alanlar, ağaçlandırma yapılmış açık yeşil alanların öğrenciler ve personelin yaşam kalitesi üzerine etkileri araştırılmıştır. Böylece, personel ve öğrencilerin görüşleri doğrultusunda kampüste bulunan açık yeşil alanlar ve parkların işlevsellik durumu, donatı ve bitkisel elemanlar açısından yeterlilikleri ve memnuniyet düzeyleri belirlenmiştir. Ayrıca, saptanan mevcut duruma göre, yapılabilecek rekreasyon çalışmaları konusunda, eksik bulunan veya ihtiyaç duyulan peyzaj tasarım uygulamalarının hayata geçirilerek yararlanma ve memnuniyet düzeylerinin artırılması doğrultusunda öneriler getirilmiştir. Çalışma kapsamında 502 kişinin görüşleri anket tekniği kullanılarak toplanmıştır. Elde edilen veriler istatistik paket programı (SPSS 20) kullanılarak analiz edilmiş ve istatistiksel analizlerde 0,05 anlamlılık düzeyi ölçüt alınmıştır. Anket tekniği ile elde edilen verilerin değerlendirilmesinde Parametrik testlerden Bağımsız örneklem t testi (Independent Samples Test) ile Tek Yönlü Varyans Testi (One Way Anova) kullanılmıştır. Farklılıkların hangi gruptan kaynaklandığııı bulmak için ise Duncan testi yapılmıștır. Bu testlerin yanında betimleyici bilgileri sunmak için frekans ve yüzde analizinden faydalanılmıştır. Sonuç olarak, Süleyman Demirel Üniversitesi açık yeşil alan ve parklarının personel ve öğrencilerin yaşam kalitesini artırdığı tespit edilmiştir.

Anahtar Kelimeler: Süleyman Demirel Üniversitesi, açık yeşil alanlar, parklar, yaşam kalitesi, personel ve öğrenci memnuniyet düzeyi, Isparta, Türkiye

\section{Effects of Parks and Green Areas on Life Quality of Student and Staff at Süleyman Demirel University}

\begin{abstract}
University education and campus contain important memories that are not forgotten in student life. In recent years, in the selection of universities by students, social life areas, parks and gardens on university campuses has become an important selection criterion. In this study, the effects of parks, squares, lawns, afforestation and open green areas of Isparta Süleyman Demirel University on the quality of life of students and staff were investigated. Thus, in line with the opinions of staff and students, the functional status of the open green areas and parks on the campus, their adequacy in terms of equipment and plant elements, and the satisfaction levels of the users were determined. In addition, according to the current situation determined, suggestions were made in order to increase the utilization and satisfaction levels by implementing the missing or needed landscape design applications in terms of recreation activities. The opinions of 502 people were collected by using questionnaire technique. The data were analyzed by using statistical package program (SPSS 20) and 0.05 significance level was taken as a criterion in statistical analysis. Independent Samples Test and One Way Anova Test were used in the evaluation of the data obtained from the questionnaire technique. Duncan test was used to find out which group was the difference. In addition to these tests, frequency and percentage analysis were used to provide descriptive information. As a result, it was determined that open green areas and parks of Süleyman Demirel University improve the quality of life of staff and students.
\end{abstract}

Keywords: Süleyman Demirel University, outdoor green space and parks, quality of life, staff and student satisfaction level, Isparta, Turkey. 


\section{Giriş}

Günümüzde teknolojinin hızlı bir şekilde ilerlemesi insanların yaşantısını kolaylaştırırken, bir takım sorunları da beraberinde getirmektedir. Örneğin; teknoloji insanların fizyolojik ihtiyaçların karşılanmasını kolaylaştırırken, ruhsal ve psikolojik ihtiyaçlarını karşılamada ise yetersiz kalmaktadır. Bu ihtiyaçların eksikliği gidermek için çabalayan insanoğlu, iç dünyasını doyuma ulaştıracak çeşitli faaliyetlere yönelmektedir. Bu faaliyetler, bireyin boş zamanlarında hoşlandığı bir işle uğraşması şeklinde olabilmekte ve insanoğlunu ruhsal ve bedensel açıdan yenilemektedir. İnsanoğlunun ruhsal ve bedensel açıdan yenilenmesini sağlayan boş zaman eylemleri, rekreasyon kavramı ile tanımlanmakta ve açıklanmaktadır Rekreasyon, tek bir eylem şeklinde yapılabileceği gibi, birden fazla eylemi de kapsayabilmektedir. Rekreasyon eylemlerinin; ev içi eylemler, kapalı yer eylemleri ve açık hava eylemleri şeklinde ayırımı bulunmaktadır. Ev içi rekreasyon eylemleri; bir barınma alanında yapılan eylemler (kitap okuma, müzik dinleme, özel hobileri yapma, vb.) olup, fiziksel olarak sınırları belli alanlarda yapılmaktadır. Kapalı yer rekreasyon eylemleri; halka açık yerlerde (sinema, tiyatro, kapalı spor salonu, vb.) yapılan eylemler (sinema veya tiyatro gösterisi, spor karşılaşması izlenmesi, vb.) olup, fiziksel sınırları ev içi eylemlere göre daha geniştir. Açık hava rekreasyon eylemleri ise; açık havada yapılan insanların istek ve ihtiyaçlarının özgürce tatmin edildiği eylemler (yürüyüş, piknik, manzara seyretme, kamp kurmak, balık tutmak, vb.) şeklinde olup, fiziksel açıdan sınırları bulunmamaktadır (Akesen, 1978; Tolunay vd., 2004).

Yaşam kalitesi, bireyin ve toplumun gelişimini etkileyen, sosyal, sağlık, ekonomik ve çevre koşullarının etkileşimi olarak tanımlamaktadır (Türksever, 2001; Ceylan, 2007).

İnsanların ruhsal doyuma ulaşmalarında en temel etkenlerden biri doğayla yakınlaşmalarıdır. Her zaman doğayla yakınlaşma imkânı bulamayan insanlar, yaşadıkları ortamları doğal hale getirmeye çalışarak, parklar ve yeşil alanlar tesis etmeye başlamışlardır.

Açık yeşil alanlar, insan ile doğa arasındaki bozulan ilişkiyi dengelemede ve şehirlerdeki yaşam koşullarının iyileştirilmesinde önemli bir rol üstlenmektedir. Gelişmiş ülkelerde yeşil alanların işlevsellik ve nitelikleri, medeniyetin ve yaşam kalitesinin bir göstergesi olarak kabul görmektedir (Gül ve Küçük, 2001). Bu sebeple, birçok gelişmiş ülke, insanların ihtiyaçlarını göz önünde bulundurarak insan yaşamı için uygun bir şehir ortamı oluşturmak için ekolojik planlama ve oluşturma çabasına girişmiştir (Akdoğan, 1987; Özbilen, 1991; Gül ve Küçük, 2001).

Günümüz insanının en önemli sorunlarından biri olan stres, insanların günlük yaşamlarında altından kalkmak zorunda oldukları iş ve yaşam mücadelesi sonucu oluşmakta, her insan kendini rahatlatacak uğraş ve aktiviteler içerisine girmektedir. Çağımızın bu hastalığıyla baş edebilmenin en iyi yollarından biri insanoğlunun kendini doğadaki canlı ve cansız varlılarla ruhunu bütünleştirmelidir. Bu her zaman mümkün olamayacağı için, insanoğlu doğal alanlara yakın ortamlar oluşturmayı hedeflemiş veya doğayı bulunduğu yere taşıma işlemini gerçekleştirmiştir. Böylece yaşam alanları ve mekânlar içerisinde veya yakınında insanların rekreatif ihtiyaçlarını karşılayacak yeşil alanlar oluşturulmuştur.

Yeşil alanlar, oluşum özelliklerine göre doğal ve yapay yeşil alanlar olmak üzere iki gruba ayrılmaktadır. Doğal yeşil alanlar, alan içerisinde bulunan flora ve faunaya ait doğal özellikleri barındıran genellikle kent etrafinda bulunmakla birlikte, yer yer kent içinde de bulunan büyük ölçeklerdeki yapılaşmamış alanlardır. Yapay yeşil alanlar ise, yapılaşmış alanlar içerisinde insanların dinlenmesi, gezinmesi, çeşitli rekreasyonel faaliyetlerini gerçekleştirmesi, psikolojik açıdan rahatlaması ve doğaya yakınlaşmalarının sağlanması amacıyla düzenlenen alanlarıdır (Yıldızcı, 1982; Keleş, 1984; Ceylan, 2007).

Kentsel yeşil alanlar, doğal ve yarı doğal ekosistemlerin insan etkisiyle birleştirilmesi sonucu oluşturulur. Bu alanlar doğa ile kent arasındaki bağlantıyı sağlar. Bu bağlamda kentsel alanlardaki yeşil bölgeler şehir etrafindaki doğal ve yarı doğal alanların yansımalarıdır (Bilgili, 2012). Kentsel yeşil alanlar, içerdiği çeşitli işlevler nedeniyle kentsel alan ve kentliler açısından çok önemli doğa parçaları olup mekânsal yapılarına ve işlevsel özelliklerine bağlı olarak kent mekânında fiziksel ve sosyal çevre bakımından faydalar üreten fonksiyon alanları şeklinde tanımlamalar yapılmış olup, yeşil alan ve parkların insan üzerindeki psikolojik etkileri ve önemi vurgulanmıştır (Ceylan, 2007).

$\mathrm{Bu}$ makalede Süleyman Demirel Üniversitesi (SDÜ) bünyesindeki yeşil alan ve parkların öğrenciler ve personelin yaşam kalitesi üzerinde psikolojik ve ruhen olarak nasıl bir olumlu etkisinin olduğu araştırılmıştır. 


\section{Materyal ve Metot}

\subsection{Araştırma alanı}

Süleyman Demirel Üniversitesi, 1992 yılında Isparta'da kurulmuş ve bünyesinde 19 Fakülte, 4 Yüksekokul, 1 Devlet Konservatuarı, ön lisans eğitim veren 21 Meslek Yüksekokulu, lisansüstü eğitim veren 6 Enstitüsü ile 46 Araştırma Uygulama Merkezinden oluşmaktadır. 2017 yılı itibari ile SDÜ mevcut toplam öğrenci sayısı 84.474 olup, SDÜ Doğu ve Batı Yerleşkelerinden yararlanan yaklaşık 64.496 öğrenci, ilçe yerleşkelerinde 19.713 bulunmaktadır. 2015-2016 yılları itibari ile ögretim elemanı sayısı 2160, idari personel sayısı ise 1342' dir. SDÜ Doğu ve Batı Yerleşkelerinin toplam alanı 643 hektardır. Bu alanın 258,552 hektarı eğitim amaçlı bina ve tesisler, 23 hektarı sosyal amaçlı bina ve tesisler, 149 hektarı spor amaçlı bina ve kapalı tesisler, 183 hektarı açık ve yeşil alanlar, 28 hektarı ise Süleyman Demirel Botanik Bahçesi alanları oluşturmaktadır (Gül ve vd., 2016). SDÜ doğal ve yapay yeşil alanları bir arada barındırmaktadır.

SDÜ yerleşkelerinde kültür merkezleri, sanat evleri, yemek salonları, kafeteryaları, spor üniteleri, banka, iletişim ve ulaştırma ofisleri, yurtları, eğlence mekânları, öğrenci meydanı ve şenlikleriyle canlı bir yaşam alanıdır. Çok amaçlı Atatürk Kapalı Spor Salonu (basketbol, voleybol, fitness, step, aerobik, tırmanma duvarı ve masa tenisi vb), olimpik yüzme havuzu ve açık alanda çim saha futbol, basketbol, hentbol, voleybol, amfi tiyatro, halı saha, 1 adet futbol sahası, tenis kortları, atletizm pisti vb. alanlar mevcuttur.
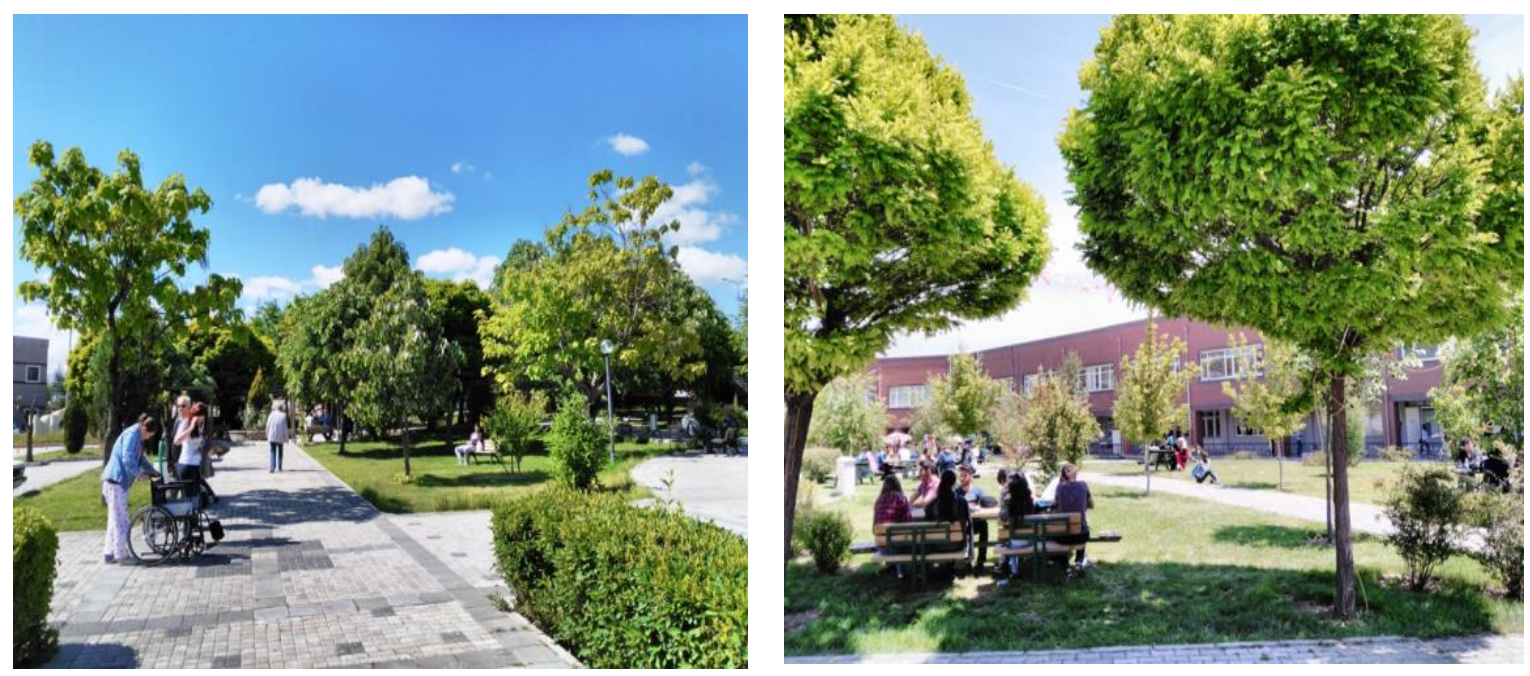

Şekil 1. SDÜ park ve bahçelerinden görüntüler

İlk kurulan üniversitelerin önemli bir bölümü ile günümüzde kurulan üniversitelerin neredeyse tamamına yakını kampüs üniversiteleri şeklinde kurulmuştur. Dolayısıyla üniversite yerleşkelerinin planlanmasında, peyzaj planlama ve tasarım ilkelerinin de göz önünde tutulması gereklidir. Bu kapsamda; SDÜ yerleşkelerinin öğrencilerin rekreatif ihtiyaçlarını da karşılamaları için kuruluşundan itibaren açık yeşil alan ve ağaçlandırma çalışmaları yapılmış olup, halen devam etmektedir. 

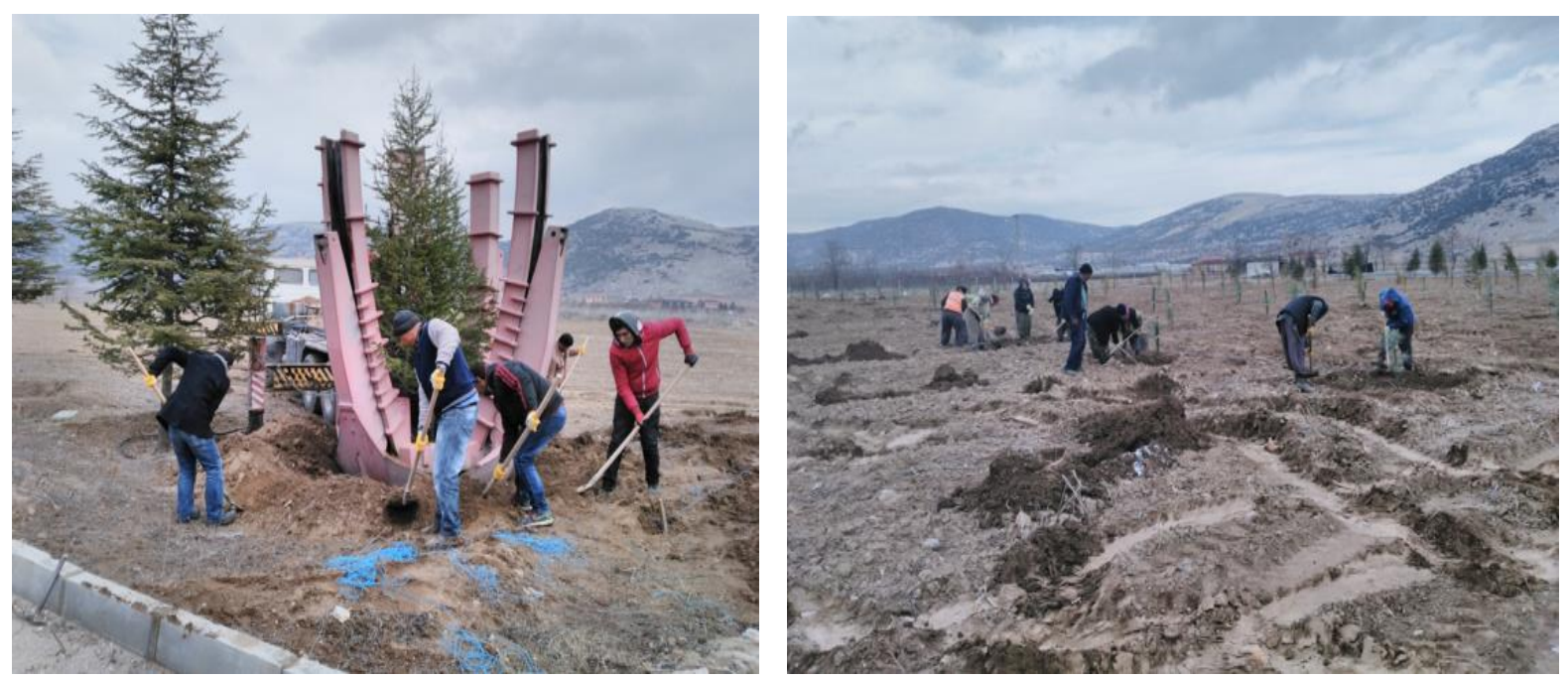

Şekil 2. SDÜ Doğu - Batı yerleşkeleri ağaçlandırma çalışmaları

SDÜ Lisans ve Lisansüstü eğitim programlarına kayıtlı ögrenci sayıları büyük bir ivmelenme kazanarak son yıllarda sürekli artış göstermiştir. Bu da SDÜ' nün her geçen yıl öğrenci kapasitesini artırarak daha çok öğrenciye ev sahipliği yapacağı anlamı taşımaktadır. Öğrenci kapasitesi arttıkça, yerleşkelerdeki sosyal ihtiyaçlarda buna paralel olarak artış göstermektedir. Belirtilen sayıda öğrenciye sahip olan böyle bir merkez yerleşkede aktif bir yașam söz konusu olup, öğrenciler ve çalıșanların tüm ihtiyaçlarını karşılayabilecek bir yapıya sahip olması gerekmektedir.

Eğitim öğretim için gerekli olan mimari yapılar ve binalar haricinde, insanların sosyal aktiviteleri için alanlar, dinlendirici ve eğlendirici özellikte açık yeşil alan ve parklar, ağaçlıklı alanlar, aktif ve pasif açık rekreasyon alanları, taşıt yolları, yaya kaldırımları, çeşme, heykel, anıt gibi objeler, bağlantı yolları, bank ve kameriye gibi ahşap dış mekan elemanları gibi yapılar gereklidir.

Üniversite kampüslerinde açık ve yeșil alanlar öğrencilerin huzurlu bir ortamda bulunması açısından genelde bir park ş̧eklinde planlanması önemlidir. Üniversite kampüsleri planlanırken, eğitim-öğretim ve barınma işlevlerinin yanı sıra, rekreasyon işlevlerini de karşılamasına özen gösterilir. Spor tesisleri, kültürel tesisler ile açık ve yeşil alan düzenlemeleri ve bu mekânları birbirine bağlayan yollar kampüs peyzajı içerisinde yoğun kullanıma sahiptir. Bundan dolayı bu ağ sistemini planlarken, kampüs içerisinde rahat ve etkin dolaşımı sağlayabilmek ve istenilen noktaya en kısa sürede ulaşabilmek büyük önem taşır (Yılmaz, 1998; Ertekin ve Çorbac1, 2010).

Üniversite yerleșkelerinde, yeșil alanlar önemli bazı ișlevleri bulunmaktadır. Bunlar; yapılarla kampüsün arasındaki bütünlüğ̈̈ sağlamak; yerleşke de rekreasyon ihtiyaçlarını karşılayacak dış mekan düzenlemesine imkan sağlamak; kampüsün sınırları içinde insanla çevresi arasında ilişkinin oluşturulması; kampüsün fiziksel gelişimi karşılamak için alanlar oluşturmak; kampüse estetik açıdan değer kazandırmak şeklinde belirtilebilir (Karakaş, 1999; Ertekin ve Çorbac1, 2010).

SDÜ yıllar içinde öğrenci sayısı bakımından büyük bir ivmelenme göstermiş olup, öğrenci sayısı sürekli artmış ve buna paralel olarak rekreatif alanlara olan talep yükselmiştir.

Calıșma 2015-2016 yılları arasında yapılmıș ve çalıșmaya sadece SDÜ personel ve öğrencileri katılmıștır. SDÜ 2015-2016 yılları arasında doğu - batı yerleşkelerinde tek üniversite konumundayken 2018 yılında yaşanılan bölünme ile SDÜ ikiye bölmüş olup Isparta Uygulamalı Bilimler Üniversitesi kurulmuştur. Şu an da SDÜ doğu batı yerleşkeleri içerisinde SDÜ ve ISUBÜ olarak iki üniversite bulunmaktadır.

\subsection{Materyal}

Araştırmanın birincil verileri anket tekniğinden yararlanılarak elde edilmiștir. İkincil veriler ise bu konuda yapılan çalışmalar, kitaplar taranarak elde edilmiştir. Çalışmanın evrenini SDÜ de çalışan personel ve öğrenciler 
oluşturmaktadır.

\subsection{Metot}

Çalışmada "Süleyman Demirel Üniversitesi Yerleşkelerinde Bulunan Yeşil Alan ve Parkların Öğrenciler ve Personelin Yaşam Kalitesi Üzerine Etkileri” araştırılmıştır. Çalışma yöntemi, gözlem ve anket çalışması olarak iki şekilde yürütülmüştür. Gözlem çalışmasında değişik gün ve saatlerde Üniversitenin doğu ve batı yerleşkelerini kullanan öğrenciler ve çalışan personellerin nasıl kullandıkları gözlenerek notlar alınmıştır.

Anket çalışmasında ise, araştırma amacı doğrultusunda hazırlanan anket formları öğrenciler ve çalışan personellere verilmiş ve doldurmaları istenmiştir. Anket uygulamasında örnek büyüklüğü eşitliğinden hesaplanmıştır (Baş, 2005). (Formül 1);

$$
\mathrm{n}>[\mathrm{N} * \mathrm{t} 2 * \mathrm{p} * \mathrm{q}] /[\mathrm{d} 2 *(\mathrm{~N}-1)+\mathrm{t} 2 * \mathrm{p} * \mathrm{q}]
$$

Burada örnekleme alınacak sayı (n), ana kütle büyüklüğü $(\mathrm{N})$, güven kat sayısı (t: \%95'lik güven için bu katsayı 1,96 alınmaktadır), ölçmek istenilen özelliğin ana kütlede bulunma ihtimali (p), ölçmek istenilen özelliğin ana kütlede bulunmama ihtimali (q) ve kabul edilen örnekleme hatası (d: \% 10)'dir. SDÜ doğu - batı yerleşkelerinde toplam 67.998 personel ve ögrencisi olup \%95 güven düzeyinde uygulanması gereken anket formu miktarı örnek büyüklüğü formülü ile 96 olarak hesaplanmıştır. Ancak yapılan çalışmada daha gerçekçi ve sağlıklı sonuçlara ulaşabilmek adına katılımcı sayısı artırılarak, toplam 502 kişi üzerinde anket uygulaması yapılmıştır. Anket formları değerlendirilerek, gözlem çalışmalarıyla elde edilen verilerle birlikte bulgular ve sonuçlara ulaşılmıştır.

Anket formunda toplam 20 adet soru mevcut olup, ilk 5 soruda; araştırmaya katılanların cinsiyeti, yaşı, eğitimi, medeni durumu ve çalışma pozisyonu olmak üzere demografik özelliklerine ilişkin sorular mevcuttur. Anket formunda yer alan 6. - 20. soruları arasında ise katılımcıların SDÜ yerleşkelerinde ki yeşil alan ve parklara bakış açısının araştırıldığı soruları içermekte olup 5'li likert ölçeği kullanılmıştır. Hiç katılmıyorum (1), katılmıyorum (2), fikrim yok (3), katılıyorum (4) ve tamamen katılıyorum (5) şeklindedir. Bilgi ve önerileri içeren sorular ise araştırma katılımcılarının cevaplarına göre düzenlenmiştir. Elde edilen verilerin değerlendirilmesi için SPSS 20 istatistik paket programından yararlanılmış ve istatistiksel analizlerde 0,05 anlamlılık düzeyi ölçüt alınmıştır.

Anket tekniği ile elde edilen verilerin değerlendirilmesinde Parametrik testlerden Bağımsız örneklem t testi (Independent Samples Test) ile Tek Yönlü Varyans Testi (One Way Anova) kullanılmıştır. Farklılıkların hangi gruptan kaynaklandığını bulmak için ise Duncan testi yapılmıştır. Bu testlerin yanında betimleyici bilgileri sunmak için frekans ve yüzde analizinden faydalanılmıştır.

Çalışmada kullanılan yardımcı yöntemler ise literatür ve doküman analizi olmuştur. Literatür analiziyle daha önce yapılmış bilimsel çalışmalar (tezler, makaleler, araştırmalar, projeler vb.) taranarak konuyla ilgili bilimsel bilgiler toplanmıştır. Doküman analizi ile konuyla ilgili resmi kurumlardan gerekli harita, bilgi, istatistik vb. gibi dokümanlar ve veriler toplanmıştır.

\section{Bulgular ve Tartışma}

\subsection{Frekans ve Oransal Analiz Bulguları}

Araştırmaya katılanların \% 48,4,'ü bayan iken, \% 51,6'sı erkektir.

Araştırmaya katılanların \% 78,1'i 18-29 yaş aralığında, \%12,7'si 30-39 yaş aralığında, \% 8,8'i 40-49 yaş aralığında, \% 0,4’ü 50-59 yaş aralığında bulunmaktadır.

Araştırmaya katılanların \% 86,7’si lisans, \% 7,4’ü lisansüstü, \%6,0’1 lise eğitimi almıştır.

Araştırmaya katılanların \% 76,9’u bekar, \% 23,1'i evlidir.

Araştırmaya katılanların \% 76,3'ü öğrenci, \%13,1'i idari personel, \% 7,2'si akademik personel, \% 3,4'ü işçidir. 
Araştırmaya katılanlara yeşil alan ve parklarda en çok yaptıkları aktivitelere ilişkin bilgiler sorulduğunda ise araştırmaya katılanların \% 56,8'i yeşil alan ve parklarda oturup dinlenmeyi tercih ederken, \% 18,5 'i yürüyüş yapmayı, \% 16,9’u çevreyi izlemeyi, \% 5,0’’ gazete, kitap vs. okumayı tercih etmektedirler.

Araştırmaya katılanlara yeşil alan ve parklardan yararlanma sıklığına ilişkin bilgiler sorulduğunda \% 49,6'sı yeşil alan ve parklardan hiç yararlanmadığını belirtirken, \% 33,1'i ayda 1-15 gün yararlandığını, \% 10,4'ü ayda 1-23 gün yararlandığını, \% 6,0'^ ayda 1-30 gün yararlandığını, \% 0,2'si ayda 1-7 gün yararlandıklarını belirtmişlerdir.

Araştırmaya katılanlara yeşil alan ve parklardan memnuniyet düzeyine ilişkin bilgiler sorulduğunda \% 33,3’ü yeşil alan ve parklardan memnun olduğunu belirtirken, \% 27,9'u kararsız olduğunu, \% 24,7'si memnun olmadığını, \% 9,4'ü hiç memnun olmadığını, \% 4,8'i çok memnun olduğunu belirtmişlerdir.

Araştırmaya katılanlara yeşil alan ve parkların bakımlarından memnuniyet düzeylerine ilişkin bilgiler sorulduğunda araştırmaya katılanların \%34,9'u yeşil alan ve parkların bakımlarından memnun olduğunu belirtirken, \% 27,3'ü memnun olmadığını, \% 26,7'si kararsız olduğunu, \% 6,2'si hiç memnun olmadığını, \% 5,0 '1 çok memnun olduğunu belirtmişlerdir.

Araştırmaya katılanlara yeşil alan ve parkların yeterliliğine ilişkin bilgiler sorulduğunda ise araştırmaya katılanların \% 48,2'si yeşil alan ve parkların yeterli olduğuna katılmadıklarını belirtirken, \% 18,1'i yeşil alan ve parkların yeterli olduğuna katıldıklarını, \% 16,7'si yeşil alan ve parkların yeterli olduğuna tamamen katılmadıklarını, \% 14,3'ü fikrinin olmadığını, \% 2,6'sı yeşil alan ve parkların yeterli olduğuna tamamen katıldıklarını belirtmişlerdir.

Araştırmaya katılanlara yeşil alan ve parklarda donatı elemanlarının yeterliliğine ilişkin bilgiler sorulduğunda araştırmaya katılanların \% 53,2'si yeşil alan ve parkların donatı elemanlarının yeterli olduğuna katılmadıklarını belirtirken, \% 25,3'ü tamamen katılmadıklarını, \% 11,2'si donatı elemanlarının yeterli olduğuna katıldıklarını, \% 7,8'si fikrinin olmadığını, \% 2,6'sı tamamen katıldıklarını belirtmişlerdir.

Araştırmaya katılanlara yeşil alan ve parklarda flora çeşitliliğinin yeterliliğine ilişkin bilgiler sorulduğunda \% 54,0’1 yeşil alan ve parklarda flora çeşitliliğinin yeterli olduğuna katılmaz iken, \% 16,9'u tamamen katılmadığını, \% 14,7’si fikrinin olmadığını, \% 12,2'si flora çeşitliliğinin yeterliliğine katıldıklarını, \% 2,2'si tamamen katıldıklarını belirtmişlerdir.

Araştırmaya katılanlara yeşil alan ve parklarda çay bahçesi ve kafeterya isteklerine ilişkin bilgiler sorulduğunda \% 39,4'ü yeşil alan ve parklarda çay bahçesi ve kafeterya sayısının artırılmasına katılırken, \% 37,5'i tamamen katıldıklarını, \% 8,0’’ fikrinin olmadığını, \% 7,8’i çay bahçesi ve kafeterya sayısının artırılmasına katılmadıklarını, \% 7,4’ü tamamen katılmadıklarını belirtmişlerdir.

Araştırmaya katılanlara yeşil alan ve parklara istenilen ilave tesislere ilişkin bilgiler sorulduğunda \% 30,9'u yeşil alan ve parklarda istenilen ilave tesislere yürüyüş yolu cevabını verirken, \% 25,7'si süs havuzu, \% 14,9'u kuş yuvası, \% 11,2'si çeşme, \% 9,6'sı tuvalet, \% 4,6’sı hepsini, \% 2,0’1 kafe, \% 0,6 bisiklet yolu, \% 0,4'ü bankların artırılması, \% 0,2'si kitaplık istediklerini belirtmişlerdir.

Araştırmaya katılanlara yeşil alan ve parkların faydalarına ilişkin bilgiler sorulduğunda \% 51,8'i yeşil alan ve parkların en önemli faydasının rahatlatma, dinlendirme olduğunu belirtirken, \% 22,5 doğayla yakınlaşmayı sağladığını, \% 13,7'si çevreyi güzelleştirdiğini, \% 8,2'si havayı temizlediğini, \% 3,8'i spor olanağı sağladığını belirtmişlerdir.

Araştırmaya katılanlara yeşil alan ve parklarda ortalama kalış sürelerine ilişkin bilgiler sorulduğunda \% 70,5'i yeşil alan ve parklarda ortalama kalış sürelerinin 0-2 saat olduğunu belirtirken, \% 21,7'si 2-4 saat, \% 5,4'ü 4-6 saat, \% 2,4’ü 6-8 saat olduğunu belirtmişlerdir.

Araştırmaya katılanlara yeşil alan ve parkları hangi mevsimde tercih ettiklerine ilişkin bilgiler sorulduğunda \% 66,1 'i yeşil alan ve parkları ilkbahar mevsiminde tercih ettiklerini belirtirken, $\% 23,1$ 'i yaz mevsiminde, $\% 6,2$ 'si sonbahar mevsiminde, \% 2,4'ü tüm mevsimlerde, \% 2,2'si kış mevsiminde tercih ettiklerini belirtmişlerdir. 
Araştırmaya katılanlara yeşil alan ve parklarda hangi ağaçları tercih ettiklerine ilişkin bilgiler sorulduğunda \% 50,4'ü yeşil alan ve parklarda altları tam gölgeli, boylu ve sık ağaçları tercih ettiklerini belirtirken, $\% 42,8$ ' $\mathrm{i}$ altları yarı gölgeli boylu ağaçları, \% 6,8'i altları bol güneşli, boylu ve seyrek ağaçları tercih ettiklerini belirtmişlerdir.

Araştırmaya katılanlara yeşil alan ve park alanları içerisine bisiklet yolu ve spor aletleri eklenmesine ilişkin bilgiler sorulduğunda $\% 42,8^{\prime} \mathrm{i}$ yeşil alan ve parklara bisiklet yolu ve spor aletleri eklenmesine katıldıklarını belirtirken, \% 34,1'i tamamen katıldığını, \% 11,0'ı bisiklet yolu ve spor aletleri eklenmesine katılmadığını, \% 8,0 '1 bisiklet yolu ve spor aletleri eklenmesi konusunda fikrinin olmadığını, \% 4,2'si bisiklet yolu ve spor aletleri eklenmesine tamamen katılmadığını belirtmişlerdir.

Araştırmaya katılanlara peyzaj alanlarının eğitim çalışmalarında kullanılmasına ilişkin bilgiler sorulduğunda \% 38,0'1 peyzaj alanlarının eğitim çalışmalarında kullanılmak üzere yeterli olduğuna katılmadığını belirtirken, \% 31,5'i fikrinin olmadığını, \% 15,5'i peyzaj alanlarının yeterli olduğuna katıldığını, \% 11,4'ü peyzaj alanlarının yeterli olduğuna tamamen katılmadığını, \% 3,6'sı peyzaj alanlarının yeterli olduğuna tamamen katıldığını belirtmişlerdir.

\subsection{Araştırmaya Katılanların Cinsiyetlerine Göre Yapılan Bağımsız Örneklem t Testi Sonuçları}

Araştırmaya katılanların cinsiyetlerine göre yapılan bağımsız örneklem $t$ testi sonuçları Tablo 1 'de verilmiştir. Araştırmaya katılanların Üniversitesi yeşil alan ve parklarının memnuniyet düzeyleri $(\mathrm{p}<0,05)$ cinsiyete göre değişmektedir. İstatistiksel olarak erkeklerin memnuniyet düzeyleri kadınlara göre daha fazla olduğu tespit edilmiştir.

Tablo 1. Araştırmaya katılanların cinsiyetlerine göre yapılan bağımsız örneklem t testi sonuçlar

\begin{tabular}{|c|c|c|c|c|c|c|c|}
\hline \multirow{2}{*}{\multicolumn{2}{|c|}{ Cinsiyete Göre }} & \multicolumn{3}{|c|}{ Levene Testi } & \multicolumn{3}{|c|}{ t-testi sonuçları } \\
\hline & & \multirow{2}{*}{$\begin{array}{c}\mathbf{N} \\
243\end{array}$} & \multirow{2}{*}{$\begin{array}{c}\mathbf{F} \\
12,673\end{array}$} & \multirow{2}{*}{$\begin{array}{l}\text { Sig. } \\
, 000\end{array}$} & \multirow{2}{*}{$\begin{array}{c}\mathbf{t} \\
-1,264\end{array}$} & \multirow{2}{*}{$\begin{array}{l}\text { df } \\
500\end{array}$} & \multirow{2}{*}{$\begin{array}{l}\text { Sig. (p) } \\
, 207\end{array}$} \\
\hline SDÜ yeşil alan ve parklarınc & Varyanslar eşit & & & & & & \\
\hline $\begin{array}{l}\text { yaptığınız aktivite aşağıdakilerden } \\
\text { hangisidir.? }\end{array}$ & $\begin{array}{l}\text { Varyanslar eşit } \\
\text { değil }\end{array}$ & 259 & & & $-1,273$ & 490,386 &, 204 \\
\hline \multirow{2}{*}{$\begin{array}{l}\text { SDÜ yeşil alan ve parklarından ne kadar } \\
\text { sıklıkta yararlanıyorsunuz? }\end{array}$} & Varyanslar eşit & 243 & \multirow[t]{2}{*}{,038 } & \multirow[t]{2}{*}{846} &,- 502 & 500 & ,616 \\
\hline & $\begin{array}{l}\text { Varyanslar eşit } \\
\text { değil }\end{array}$ & & & &,- 503 & 498,722 & ,615 \\
\hline \multirow{2}{*}{$\begin{array}{l}\text { SDÜ yeşil alan ve parklarından ne kadar } \\
\text { memnunsunuz? }\end{array}$} & Varyanslar eşit & 243 & \multirow[t]{2}{*}{,739 } & \multirow[t]{2}{*}{,390 } & ,288 & 500 & ,774 \\
\hline & $\begin{array}{l}\text { Varyanslar eşit } \\
\text { değil }\end{array}$ & 259 & & & 288 & 499,116 & ,774 \\
\hline \multirow{2}{*}{$\begin{array}{l}\text { SDÜ yeşil alan ve parklarının } \\
\text { bakımlarından memnun musunuz? }\end{array}$} & Varyanslar eşit & $\begin{array}{l}243 \\
250\end{array}$ & \multirow[t]{2}{*}{,048 } & \multirow[t]{2}{*}{827} & $-2,660$ & 500 &, $008^{*}$ \\
\hline & $\begin{array}{l}\text { Varyansiar eşit } \\
\text { değil }\end{array}$ & & & & $-2,660$ & 498,084 & ,008 \\
\hline \multirow{2}{*}{$\begin{array}{l}\text { SDÜ yerleşkelerinde bulunan yeşil alan ve } \\
\text { park alanları yeterlidir? }\end{array}$} & Varyanslar eşit & 243 & \multirow[t]{2}{*}{,003 } & \multirow[t]{2}{*}{, 957} &,- 525 & 500 & ,599 \\
\hline & $\begin{array}{l}\text { Varyanslar eşit } \\
\text { değil }\end{array}$ & 259 & & &,- 526 & 498,440 &, 599 \\
\hline \multirow{2}{*}{$\begin{array}{l}\text { SDÜ yerleşkelerinde bulunan yeşil alan ve } \\
\text { parkların donatı elemanları (Bank, masa, } \\
\text { kamelya, vs...) yeterlidir. }\end{array}$} & Varyanslar eşit & 243 & \multirow[t]{2}{*}{052} & \multirow[t]{2}{*}{, 819} &,- 402 & 500 & ,688 \\
\hline & $\begin{array}{l}\text { Varyanslar eşit } \\
\text { değil }\end{array}$ & 259 & & &,- 402 & 498,033 & ,688 \\
\hline \multirow{2}{*}{$\begin{array}{l}\text { SDÜ yerleşkelerinde bulunan yeşil alan ve } \\
\text { park alanları flora çeşitliliği (bitki örtüsü) } \\
\text { yeterlidir. }\end{array}$} & Varyanslar eşit & 243 & \multirow[t]{2}{*}{3,609} & \multirow[t]{2}{*}{, 058} & $-1,558$ & 500 &, 120 \\
\hline & $\begin{array}{l}\text { Varyanslar eşit } \\
\text { değil }\end{array}$ & 259 & & & $-1,562$ & 499,854 & , 119 \\
\hline \multirow{2}{*}{$\begin{array}{l}\text { SDÜ içerisinde bulunan yeşil alan ve park } \\
\text { alanları içerisinde çay bahçesi, kafeterya, } \\
\text { vs., sayısı artırılmalıdır. }\end{array}$} & Varyanslar eşit & 243 & \multirow[t]{2}{*}{,001 } & \multirow[t]{2}{*}{, 975} &,- 086 & 500 & ,931 \\
\hline & $\begin{array}{l}\text { Varyanslar eşit } \\
\text { değil }\end{array}$ & 259 & & &,- 086 & 496,355 & ,931 \\
\hline \multirow{2}{*}{$\begin{array}{l}\text { SDÜ içerisinde bulunan yeşil alan ve park } \\
\text { alanları ne gibi ilave tesisler yapılmalıdır? }\end{array}$} & Varyanslar eşit & 243 & \multirow[t]{2}{*}{, 141} & \multirow[t]{2}{*}{, 708} & ,457 & 500 & 648 \\
\hline & $\begin{array}{l}\text { Varyanslar eşit } \\
\text { değil }\end{array}$ & 25 & & & ,456 & 494,790 & 6 \\
\hline Sizce yeşil alan ve parkların en önemli & Varyanslar eşit & 243 & , 000 & ,992 &,- 308 & 500 & ,758 \\
\hline
\end{tabular}


faydası nedir?

Varyanslar eşit değil

SDÜ içerisinde bulunan yeşil alan ve park Varyanslar eşit alanları içerisinde ortalama kalış süreniz Varyanslar eşit ne kadardır? değil

SDÜ içerisinde bulunan yeşil alan ve park Varyanslar eşit alanlarını hangi mevsim de tercih Varyanslar eşit ediyorsunuz? değil

SDÜ içerisinde dinlenme amacıyla aşağıda Varyanslar eşit özellikleri sayılan ağaçlardan hangisini Varyanslar eşit tercih edersiniz? değil

SDÜ içerisinde bulunan yeşil alan ve park Varyanslar eşit alanları içerisine bisiklet yolu ve spor aletleri eklenmelidir. Varyanslar eşit değil

SDÜ içerisinde bulunan peyzaj alanları bilimsel veya uygulamalı eğitim Varyanslar eşit Varyanslar eşit

259

243 259 243 259 259 243 259 243 259 243 259

\begin{tabular}{rrrrr} 
& &,- 308 & 498,154 &, 758 \\
23,429 &, 000 & 1,466 & 500 &, 143 \\
& & 1,479 & 475,021 &, 140 \\
, 691 &, 406 &, 208 & 500 &, 835 \\
& &, 208 & 488,104 &, 836 \\
, 197 &, 657 &, 204 & 500 &, 838 \\
& &, 204 & 499,338 &, 838 \\
1,467 &, 226 & $-1,101$ & 500 &, 272 \\
& & $-1,100$ & 495,525 &, 272 \\
1,668 &, 197 &, 131 & 500 &, 896 \\
& &, 131 & 499,981 &, 896 \\
\hline
\end{tabular}
çalışmalarında kullanılmak için yeterlidir değil $*(p)<0,05$ Anlamlı farklılık vardır

\subsection{Araştırmaya Katılanların Yaş Dağııımlarına Göre Yapılan One-Way Anova Testi Sonuçları}

Araştırmaya katılanların yaş dağılımlarına göre anket sorularına verdikleri cevaplar yönünden farklılığın belirlenmesinde yapılan One-Way Anova Testi yapılmıştır. Ano-Way Anova Testi sonucunda p<0,05 değer (en küçük 0,058, en büyük 0,932) almayarak araştırmaya katılanların yaş dağılımlarına göre verdikleri cevaplar yönünden istatistiksel olarak fark bulunmamıştır.

\subsection{Araştırmaya Katılanların Eğitim Durumlarına Göre Yapılan One-Way Anova Testi Sonuçları}

Araştırmaya katılanların eğitim durumlarına göre yapılan One-Way Anova Testi sonuçları Tablo 2'de ve Duncan testi sonucu Tablo 4'te verilmiştir. Üniversite yeşil alan ve parklarda en çok yapılan aktivite durumu $(\mathrm{p}<0,05)$ eğitim durumuna göre farklılık göstermektedir.

Tablo 2. Araştırmaya katılanların eğitim durumlarına göre yapılan One-Way Anova Testi sonuçları

\begin{tabular}{|c|c|c|c|c|c|c|}
\hline \multicolumn{2}{|l|}{ Eğitim durumlarına göre } & \multirow{2}{*}{$\begin{array}{r}\begin{array}{r}\text { Kareler } \\
\text { Toplamı }\end{array} \\
6,041\end{array}$} & \multirow{2}{*}{$\frac{\text { df }}{2}$} & $\begin{array}{c}\text { Kareler } \\
\text { Ortalaması }\end{array}$ & \multirow{2}{*}{$\frac{\mathbf{F}}{4,621}$} & \multirow{2}{*}{$\begin{array}{l}\text { Sig. } \\
\text { (p) } \\
, 010^{*}\end{array}$} \\
\hline$\overline{\text { SDÜ yeşil alan ve parklarında en çok }}$ & Gruplar arasında & & & 3,021 & & \\
\hline yaptığınız aktivite aşağıdakilerden & Gruplar içinde & 326,166 & 499 & 654 & & \\
\hline hangisidir? & Toplam & 332,207 & 501 & & & \\
\hline \multirow{3}{*}{$\begin{array}{l}\text { SDÜ yeşil alan ve parklarından ne kadar } \\
\text { sıklıkta yararlanıyorsunuz? }\end{array}$} & Gruplar arasinda & ,039 & 2 &, 020 & 011 & ,989 \\
\hline & Gruplar içinde & 898,823 & 499 & 1,801 & & \\
\hline & Toplam & 898,863 & 501 & & & \\
\hline \multirow{3}{*}{$\begin{array}{l}\text { SDÜ yeşil alan ve parklarından ne kadar } \\
\text { memnunsunuz? }\end{array}$} & Gruplar arasinda & 4,147 & 2 & 2,074 & 1,813 & 164 \\
\hline & Gruplar içinde & 570,835 & 499 & 1,144 & & \\
\hline & Toplam & 574,982 & 501 & & & \\
\hline \multirow{3}{*}{$\begin{array}{l}\text { SDÜ yeşil alan ve parklarının bakımlarından } \\
\text { memnun musunuz? }\end{array}$} & Gruplar arasında & 3,269 & 2 & 1,635 & 1,535 & ,216 \\
\hline & Gruplar içinde & 531,384 & 499 & 1,065 & & \\
\hline & Toplam & 534,653 & 501 & & & \\
\hline \multirow{3}{*}{$\begin{array}{l}\text { SDÜ yerleşkelerinde bulunan yeşil alan ve } \\
\text { park alanları yeterlidir? }\end{array}$} & Gruplar arasinda & 2,895 & 2 & 1,447 & 1,320 & ,268 \\
\hline & Gruplar içinde & 547,091 & 499 & 1,096 & & \\
\hline & Toplam & 549,986 & 501 & & & \\
\hline \multirow{5}{*}{$\begin{array}{l}\text { SDÜ yerleşkelerinde bulunan yeşil alan ve } \\
\text { parkların donatı elemanları (Bank, masa, } \\
\text { kamelya, vs...) yeterlidir. } \\
\text { Süleyman Demirel Üniversitesi } \\
\text { yerleşkelerinde bulunan yeşil alan ve park }\end{array}$} & Gruplar arasında & ,244 & 2 &, 122 &, 122 &, 885 \\
\hline & Gruplar içinde & 498,849 & 499 & 1,000 & & \\
\hline & Toplam & 499,094 & 501 & & & \\
\hline & Gruplar arasinda & ,241 & 2 &, 121 &, 131 & 877 \\
\hline & Gruplar içinde & 460,452 & 499 & ,923 & & \\
\hline
\end{tabular}


alanları flora çeşitliliği (bitki örtüsü)

yeterlidir.

SDÜ içerisinde bulunan yeşil alan ve park alanları içerisinde çay bahçesi, kafeterya, vs., sayısı artırılmalıdır.

SDÜ içerisinde bulunan yeşil alan ve park alanları ne gibi ilave tesisler yapılmalıdır?

Sizce yeşil alan ve parkların en önemli faydası nedir?

SDÜ içerisinde bulunan yeşil alan ve park alanları içerisinde ortalama kalış süreniz ne kadardır?

SDÜ içerisinde bulunan yeşil alan ve park alanlarını hangi mevsim de tercih ediyorsunuz?

SDÜ içerisinde dinlenme amacıyla aşağıda özellikleri sayılan ağaçlardan hangisini tercih edersiniz?

SDÜ içerisinde bulunan yeşil alan ve park alanları içerisine bisiklet yolu ve spor aletleri eklenmelidir.

SDÜ içerisinde bulunan peyzaj alanları bilimsel veya uygulamalı eğitim çalışmalarında kullanılmak için yeterlidir $*(\mathrm{p})<0,05$ Anlamlı farklılık vardır
Toplam

Gruplar arasında

Gruplar içinde

Toplam

Gruplar arasında

Gruplar içinde

Toplam

Gruplar arasında

Gruplar içinde

Toplam

Gruplar arasinda

Gruplar içinde

Toplam

Gruplar arasında

Gruplar içinde

Toplam

Gruplar arasinda

Gruplar içinde

Toplam

Gruplar arasinda

Gruplar içinde

Toplam

Gruplar arasında

Gruplar içinde

Toplam
$460,693 \quad 501$

$2,375 \quad 2$

$1,187 \quad, 833 \quad, 435$

$711,276 \quad 499$

$713,651 \quad 501$

$2,217 \quad 2$

1,425

1,108

, 305

$1813,164 \quad 499$

$1815,380 \quad 501$

1,212

$445,856 \quad 499$

$447,068 \quad 501$

,766 2

$160,851 \quad 499$

$161,618 \quad 501$

$1,405 \quad 2$

$275,506 \quad 499$

$276,910 \quad 501$

$124 \quad 2$

3,634

606 ,508

,893

,383 1,188 ,306

,322

,702 $1,272 \quad, 281$

,552

, 062

, 168

$183,615 \quad 499$

$183,739 \quad 501$

, $541 \quad 2$

$615,945 \quad 499$

$616,486 \quad 501$

, $523 \quad 2$

,368

,271

1,234

,219

$495,805 \quad 499$

$496,329 \quad 501$

,262

,994

Farklılığın hangi eğitim düzeyine sahip bireyler yönünden kaynaklandığı tespit etmek amacıyla yapılan Duncan testi sonucu Tablo 3'te gösterilmiştir. Buna göre lisansüstü eğitime sahip bireylerin bu alanlardan faydalanma düzeyi ile lise mezunu bireylerin faydalanma şekli farklılık göstermektedir. Lisansüstü eğitime sahip kişiler bu alanları yürüyüş yapmak için kullanırken, lise ve lisans mezunları daha çok oturmak ve dinlenmek için kullanmaktadır.

Çizelge 3. Duncan testi sonucu

\begin{tabular}{|c|c|c|c|}
\hline \multicolumn{4}{|c|}{$\begin{array}{c}\text { Süleyman Demirel Üniversitesi yeşil alan ve parklarında en çok } \\
\text { yaptığınız aktivite aşağıdakilerden hangisidir.? }\end{array}$} \\
\hline \multirow{2}{*}{ Eğitim durumu } & \multirow{2}{*}{$\mathbf{N}$} & \multicolumn{2}{|c|}{$P=0.05$} \\
\hline & & 1 & 2 \\
\hline Lise & 30 & 2,8333 & \\
\hline Lisans & 435 & 3,0460 & \\
\hline Lisansüstü & 37 & & 3,4054 \\
\hline Sig. & & 199 & 1,000 \\
\hline
\end{tabular}

\subsection{Araştırmaya Katılanların Medeni Durumlarına Göre Yapılan Bağımsız Örneklem $t$ Testi Sonuçları}

Araştırmaya katılanların medeni durumlarına göre yapılan bağımsız örneklem t testi sonuçları Tablo 4'te verilmiștir.

SDÜ yeşil alan ve parklarından memnuniyet düzeyi hakkındaki görüşler ve SDÜ içerisinde bulunan yeşil alan ve park alanları içerisine bisiklet yolu ve spor aletleri eklenmelidir önermeleri $(p<0,05)$ çalışmaya katılanların medeni durumlarına göre farklılık göstermiştir. Bu alanlardan bekârların memnuniyet düzeyi daha yüksek olduğu görülmüştür. 
Tablo 4. Araştırmaya katılanların medeni durumlarına göre yapılan bağımsız örneklem t testi sonuçları

\begin{tabular}{|c|c|c|c|c|c|c|}
\hline \multirow{2}{*}{ la } & & \multicolumn{2}{|c|}{ Levene Testi } & \multicolumn{3}{|c|}{ t-testi sonuçları } \\
\hline & & $\mathbf{F}$ & Sig. & $\mathbf{t}$ & df & Sig. (p) \\
\hline \multirow{2}{*}{$\begin{array}{l}\text { SDÜ yeşil alan ve parklarında en çok } \\
\text { yaptığınız aktivite aşağıdakilerden hangisidir.? }\end{array}$} & & ,057 & ,812 &,- 529 & 500 &, 5 \\
\hline & $\begin{array}{l}\text { Varyanslar eşit } \\
\text { değil }\end{array}$ & & &,- 545 & 198,636 &, 58 \\
\hline \multirow{2}{*}{$\begin{array}{l}\text { SDÜ yeşil alan ve parklarından ne kadar } \\
\text { sıklıkta yararlanıyorsunuz? }\end{array}$} & & ,033 &, 856 &,- 046 & 500 & ,96 \\
\hline & $\begin{array}{l}\text { Varyanslar eşit } \\
\text { değil }\end{array}$ & & &,- 046 & 189,879 & ,96 \\
\hline \multirow{2}{*}{$\begin{array}{l}\text { SDÜ yeşil alan ve parklarından ne kadar } \\
\text { memnunsunuz? }\end{array}$} & & 1,402 & ,237 & $-2,252$ & 500 &, 025 \\
\hline & $\begin{array}{l}\text { Varyan } \\
\text { değil }\end{array}$ & & & $-2,405$ & 211,009 & ,017 \\
\hline \multirow{2}{*}{$\begin{array}{l}\text { SDÜ yeşil alan ve parklarının bakımlarından } \\
\text { memnun musunuz? }\end{array}$} & & ,615 & ,433 & $-1,024$ & 500 &, 30 \\
\hline & $\begin{array}{l}\text { Varyan } \\
\text { değil }\end{array}$ & & & $-1,045$ & 195,422 &, 25 \\
\hline \multirow{2}{*}{$\begin{array}{l}\text { SDÜ yerleşkelerinde bulunan yeşil alan ve } \\
\text { park alanları yeterlidir? }\end{array}$} & & 1,827 &, 177 & ,939 & 500 &, 34 \\
\hline & $\begin{array}{l}\text { Varyanslar eşit } \\
\text { değil }\end{array}$ & & & ,967 & 198,437 &, 33 \\
\hline \multirow{4}{*}{$\begin{array}{l}\text { SDÜ yerleşkelerinde bulunan yeşil alan ve } \\
\text { parkların donatı elemanları (Bank, masa, } \\
\text { kamelya, vs...) yeterlidir. } \\
\text { SDÜ yerleşkelerinde bulunan yeşil alan ve } \\
\text { park alanları flora çeşitliliği (bitki örtüsü) } \\
\text { yeterlidir. }\end{array}$} & & 1,000 &, 318 &, 589 & 500 &, 55 \\
\hline & $\begin{array}{l}\text { Varyan } \\
\text { değil }\end{array}$ & & & ,597 & 193,427 &, 55 \\
\hline & r eşit & 8,484 & ,004 & 1,357 & 500 &, 17 \\
\hline & $\begin{array}{l}\text { Varyan } \\
\text { değil }\end{array}$ & & & 1,448 & 210,662 &, 14 \\
\hline \multirow{2}{*}{$\begin{array}{l}\text { SDÜ içerisinde bulunan yeşil alan ve park } \\
\text { alanları içerisinde çay bahçesi, kafeterya, vs., } \\
\text { sayısı artırılmalıdır. }\end{array}$} & Vary & 12,239 &, 001 & $-1,552$ & 500 & , 12 \\
\hline & $\begin{array}{l}\text { Varyanslar eşit } \\
\text { değil }\end{array}$ & & & $-1,741$ & 231,192 & 0 \\
\hline \multirow{2}{*}{$\begin{array}{l}\text { SDÜ içerisinde bulunan yeşil alan ve park } \\
\text { alanları ne gibi ilave tesisler yapılmalıdır? }\end{array}$} & lar eşit & ,083 & ,773 &, 335 & 500 &, 73 \\
\hline & Şit & & &, 331 & 186,058 &, 7 \\
\hline \multirow{2}{*}{$\begin{array}{l}\text { Sizce yeşil alan ve parkların en önemli faydası } \\
\text { nedir? }\end{array}$} & eşit & ,974 &, 324 & ,419 & 500 &, 67 \\
\hline & eşit & & & ,428 & 195,605 & 6 \\
\hline \multirow{2}{*}{$\begin{array}{l}\text { SDÜ içerisinde bulunan yeşil alan ve park } \\
\text { alanları içerisinde ortalama kalış süreniz ne } \\
\text { kadardır? }\end{array}$} & Varyan & 1,572 & ,211 &,- 092 & 500 & ,92 \\
\hline & $\begin{array}{l}\text { Varyan } \\
\text { değil }\end{array}$ & & &,- 098 & 209,354 & ,9 \\
\hline \multirow{2}{*}{$\begin{array}{l}\text { SDÜ içerisinde bulunan yeşil alan ve park } \\
\text { alanlarını hangi mevsim de tercih } \\
\text { ediyorsunuz? }\end{array}$} & Vary & ,749 & ,387 & ,984 & 500 & ,32 \\
\hline & $\begin{array}{l}\text { Varyanslar eşit } \\
\text { değil }\end{array}$ & & & 1,003 & 195,022 & ,3 \\
\hline \multirow{2}{*}{$\begin{array}{l}\text { SDÜ içerisinde dinlenme amacıyla aşağıda } \\
\text { özellikleri sayılan ağaçlardan hangisini tercih } \\
\text { edersiniz? }\end{array}$} & Varya & ,008 & ,931 &,- 380 & 500 &, 70 \\
\hline & $\begin{array}{l}\text { Varyanslar eşit } \\
\text { değil }\end{array}$ & & &,- 383 & 191,683 &, 7 \\
\hline \multirow{4}{*}{$\begin{array}{l}\text { SDÜ içerisinde bulunan yeşil alan ve park } \\
\text { alanları içerisine bisiklet yolu ve spor aletleri } \\
\text { eklenmelidir. } \\
\text { SDÜ içerisinde bulunan peyzaj alanları } \\
\text { bilimsel veya uygulamalı eğitim } \\
\text { çalışmalarında kullanılmak için yeterlidir }\end{array}$} & Vary & 12,463 &, 000 & $-2,856$ & 500 &, 00 \\
\hline & $\begin{array}{l}\text { Varyanslar eşit } \\
\text { değil }\end{array}$ & & & $-3,266$ & 240,406 &, 00 \\
\hline & Varyan & 2,626 & ,106 &,- 121 & 500 & ,9 \\
\hline & $\begin{array}{l}\text { Varyanslar eşit } \\
\text { değil }\end{array}$ & & &,- 115 & 176,437 & ,9 \\
\hline
\end{tabular}
$*(\mathrm{p})<0,05$ Anlamlı farkl111k vardır

\subsection{Araştırmaya Katılanların Çalışma Pozisyonlarına Göre Yapılan One-Way Anova Testi Sonuçları}

Katılımcıların çalışma pozisyonuna göre yapılan One-Way Anova Testi sonuçları Tablo 5'te verilmiştir. 
Tablo 5. Araştırmaya katılanların çalışma pozisyonuna göre yapılan One-Way Anova Testi sonuçları

\begin{tabular}{|c|c|c|c|c|c|c|}
\hline \multicolumn{2}{|l|}{ Çalışma Pozisyonuna } & \multirow{2}{*}{$\begin{array}{r}\begin{array}{r}\text { Kareler } \\
\text { Toplamı }\end{array} \\
8,037\end{array}$} & \multirow{2}{*}{$\frac{\text { df }}{3}$} & $\begin{array}{c}\text { Kareler } \\
\text { Ortalaması }\end{array}$ & \multirow{2}{*}{$\begin{array}{c}\mathbf{F} \\
4,116\end{array}$} & \multirow{2}{*}{$\begin{array}{c}\text { Sig. } \\
\text { (p) }\end{array}$} \\
\hline SDÜ yeşil alan ve parklarında en çok & Gruplar arasında & & & 2,679 & & \\
\hline yaptığınız aktivite aşağıdakilerden & Gruplar içinde & 324,170 & 498 & 651 & & \\
\hline hangisidir.? & Toplam & 332,207 & 501 & & & \\
\hline \multirow{3}{*}{$\begin{array}{l}\text { SDÜ yeşil alan ve parklarından ne kadar } \\
\text { s1klıkta yararlanıyorsunuz? }\end{array}$} & Gruplar arasında & 5,497 & 3 & 1,832 & \multirow[t]{3}{*}{1,021} & \multirow[t]{3}{*}{,383 } \\
\hline & Gruplar içinde & 893,366 & 498 & 1,794 & & \\
\hline & Toplam & 898,863 & 501 & & & \\
\hline \multirow{3}{*}{$\begin{array}{l}\text { SDÜ yeşil alan ve parklarından ne kadar } \\
\text { memnunsunuz? }\end{array}$} & Gruplar arasında & 8,986 & 3 & 2,995 & \multirow[t]{3}{*}{2,636} & \multirow[t]{3}{*}{,049* } \\
\hline & Gruplar içinde & 565,996 & 498 & 1,137 & & \\
\hline & Toplam & 574,982 & 501 & & & \\
\hline \multirow{3}{*}{$\begin{array}{l}\text { SDÜ yeşil alan ve parklarının bakımlarından } \\
\text { memnun musunuz? }\end{array}$} & Gruplar arasinda & 4,554 & 3 & 1,518 & \multirow[t]{3}{*}{1,426} & \multirow[t]{3}{*}{,234 } \\
\hline & Gruplar i & 530,099 & 498 & 1,064 & & \\
\hline & Toplam & 534,653 & 501 & & & \\
\hline \multirow{3}{*}{$\begin{array}{l}\text { SDÜ yerleşkelerinde bulunan yeşil alan ve } \\
\text { park alanları yeterlidir? }\end{array}$} & Gruplar arasında & 1,270 & 3 &, 423 & \multirow[t]{3}{*}{,384 } & \multirow[t]{3}{*}{,765 } \\
\hline & Gruplar i & 548,716 & 498 & 1,102 & & \\
\hline & Toplam & 549,986 & 501 & & & \\
\hline \multirow{9}{*}{$\begin{array}{l}\text { SDÜ yerleşkelerinde bulunan yeşil alan ve } \\
\text { parkların donatı elemanları (Bank, masa, } \\
\text { kamelya, vs...) yeterlidir. } \\
\text { SDÜ yerleşkelerinde bulunan yeşil alan ve } \\
\text { park alanları flora çeşitliliği (bitki örtüsü) } \\
\text { yeterlidir. } \\
\text { SDÜ içerisinde bulunan yeşil alan ve park } \\
\text { alanları içerisinde çay bahçesi, kafeterya, vs., } \\
\text { sayısı artırılmalıdır. }\end{array}$} & Gruplar arasında & 4,276 & 3 & 1,425 & \multirow[t]{3}{*}{1,435} & \multirow[t]{3}{*}{232} \\
\hline & Gru & 494,817 & 498 & ,994 & & \\
\hline & Toplam & 499,094 & 501 & & & \\
\hline & Gruplar arasında & 2,820 & 3 & ,940 & \multirow[t]{3}{*}{1,022} & \multirow[t]{3}{*}{,382 } \\
\hline & Gru & 457,874 & 498 & 919 & & \\
\hline & Top & 460,693 & 501 & & & \\
\hline & Gruplar ar & 5,029 & 3 & 1,676 & 1,178 & ,318 \\
\hline & Gruplar i & 708,623 & 498 & 1,423 & & \\
\hline & Topl & 713,651 & 501 & & & \\
\hline & Gruplar arasında & 3,937 & 3 & 1,312 & ,361 & ,781 \\
\hline & Gruplar iç & 1811,443 & 498 & 3,637 & & \\
\hline & Top & 1815,380 & 501 & & & \\
\hline & Gruplar arasinda & 1,184 & 3 & ,395 & ,441 & ,724 \\
\hline . & Gruplar & 445,884 & 498 & ,895 & & \\
\hline & To & 447,068 & 501 & & & \\
\hline park & Gru & ,508 & 3 & , 169 &, 524 & ,666 \\
\hline lanları içerisinde ortalama kalış süreniz ne & Gru & 161,109 & 498 & ,324 & & \\
\hline kadardır? & Top & 161,618 & 501 & & & \\
\hline SDÜ içerisinde & Gruplar ar &, 505 & 3 &, 168 & ,303 & ,823 \\
\hline alanlarını hang & Gru & 276,406 & 498 &, 555 & & \\
\hline ediyorsunuz? & Toplam & 276,910 & 501 & & & \\
\hline SDÜ içerisinde & Gruplar : & 1,274 & 3 & 425 & 1,159 & ,325 \\
\hline özellikleri sayılan ağaçlardan hangisini tercih & Gruplar içinde & 182,465 & 498 & ,366 & & \\
\hline edersiniz? & Toplam & 183,739 & 501 & & & \\
\hline SDÜ içerisinde & Gruplar arasinda & 6,144 & 3 & 2,048 & 1,671 & 172 \\
\hline alanları içerisine bisiklet yolu ve spor aletleri & Gruplar içinde & 610,342 & 498 & 1,226 & & \\
\hline & Toplam & 616,486 & 501 & & & \\
\hline SDÜ içerisinde $b$ & Gruplar arasında & 1,103 & 3 & ,368 & ,370 & ,775 \\
\hline bilimsel veya uygulamalı eğitim & Gruplar içinde & 495,225 & 498 & ,994 & & \\
\hline llarında kullanılmak ıçın & Toplam & 496,329 & 501 & & & \\
\hline
\end{tabular}
$*(\mathrm{p})<0,05$ Anlamlı farklılık vardır

Üniversite de yeşil alan ve parklarda en çok yapılan aktivite ve yeşil alan ve parklarından memnuniyet düzeyi hakkındaki görüşler $(\mathrm{p}<0,05)$ çalışma pozisyonuna göre farklılık göstermektedir.

Farklılığın hangi pozisyonda bulunan bireyler yönünden kaynaklandığı tespit etmek amacıyla yapılan Duncan testi sonucu aşağıda gösterilmiştir. Duncan testi sonuçları Tablo 6 ve Tablo 7'de verilmiştir. 
Tablo 6. Duncan testi sonucu

\begin{tabular}{lccc}
\hline \multicolumn{4}{c}{ Yeşil Alan ve Parklarda En Çok Yapılan Aktivite } \\
\cline { 3 - 4 } \multicolumn{1}{c}{ Pozisyonu } & $\mathbf{N}$ & $\mathbf{1}$ & $\mathbf{P = 0 . 0 5}$ \\
\cline { 3 - 4 } & 17 & 2,7647 & $\mathbf{2}$ \\
\hline İşci & 66 & 2,9848 & \\
İdari & 383 & 3,0470 & \\
Öğrenci & 36 & & 3,4722 \\
Akademisyen & &, 150 & 1,000 \\
Sig. & & &
\end{tabular}

Tablo 7. Duncan testi sonucu

\begin{tabular}{lccc}
\hline \multicolumn{3}{c}{ Yeşil Alan ve Parklarından Memnuniyet Düzeyi } \\
\hline \multirow{2}{*}{ Pozisyonu } & \multirow{2}{*}{$\mathbf{N}$} & $\mathbf{1}$ & $\mathbf{P = 0 . 0 5}$ \\
\cline { 3 - 4 } & & 1,6471 & $\mathbf{2}$ \\
\hline İşçi & 17 & & \\
Akkademik & 36 & & 2,1111 \\
Öğrenci & 383 & & 2,1358 \\
İdari & 66 & 1,000 & 2,1970 \\
Sig. & & &, 725 \\
\hline
\end{tabular}

Buna göre akademik personel bu alanları yürüyüş yapmak için kullanırken, diğerleri genellikle oturmak ve dinlenmek için kullanmaktadır. İşçilerin memnuniyet düzeylerinin diğer gruplara göre fazla olduğu tespit edilmiştir.

\subsection{Tartışma}

SDÜ personel ve öğrencilerinden araştırmaya katılanlar yeşil alan ve parklardan yararlanma sıklığına sorulduğunda yaklaşık \%50'si yeşil alan ve parklardan hiç yararlanmadığını belirtirmişlerdir. Öğrenciler, SDÜ kampüslerinin konum olarak şehrin dışında olması ve yapabilecekleri sosyal aktivitelerin şehir merkezinde daha çeşitli olduğunu düşündükleri için; personeller ise çalışma tempolarından dolayı SDÜ yeşil alan ve parklarından yararlanamadıklarını dile getirmişlerdir. Müderrisoğlu ve Uzun 2004 yılında yapmış oldukları çalışmada, Öğrencilerin üniversite yerleşkelerinde geçirdikleri süreler, kent merkezlerinde geçirilen süre açısından rekreasyonel aktivitelere katılımlarını da özellikle etkilediğini belirlenmiştir. Mete ve Ağaoğlu 2003 yılında yaptıkları çalışmada ise; Ondokuz Mayıs Üniversitesi ankete katılan personellerin yerleşkede yeterli imkân ve çalışma tempolarından dolayı zaman bulamadıkları için yerleşke dışında etkinliklere katıldıklarını ifade etmişlerdir.

SDÜ personel ve öğrencilerinden araştırmaya katılanlara yeşil alan ve parkların faydalarına ilişkin bilgiler sorulduğunda yarısından fazlası yeşil alan ve parkların en önemli faydasının psikolojik olarak rahatlatma, ruhu dinlendirme olduğunu belirtmişlerdir. Önder 2003 yılında yapmış olduğu çalışmada, Selçuk Üniversitesinin öğrencileri yapılan rekreasyonel etkinliklerin kişinin sıkıntısı atması, mutlu olmak, arkadaşlarla beraber olmak ve dinlenmek amaçlı yapıldığı ifade etmişlerdir. Huang and Carleton 2003 yılında üniversite öğrencilerine yaptıkları çalışmalarında ise, rekreasyonel aktivitelere katılımın gençlerin yaşam doyumunu artırdığını belirlemişlerdir.

Araştırmaya katılanlara yeşil alan ve park alanları içerisine bisiklet yolu ve spor aletleri eklenmesine ilişkin bilgiler sorulduğunda yaklaşık \%80'i yeşil alan ve parklara bisiklet yolu ve spor aletleri eklenmesine katıldıklarını belirtirmişlerdir. Tunçkol ve Çumralıgil 2005 yılında yapılan bir araştırmada, Selçuk Üniversitesi'nde çalışan ve anket çalışmasına katılan personellerin yaklaşık yarısı kampüs içerisinde spor faaliyetlerine katıldıklarını belirtmişlerdir. Yağmur ve Ocak 2013 yılında yaptıkları araştırmada ise, kampüs içerisinde öğrencilerin serbest zaman tercih seçeneklerinde spor ve oyun etkinliklerinin daha yoğun olduğunu tespit etmişlerdir. 


\section{Sonuç ve Öneriler}

$\mathrm{Bu}$ çalışma ile SDÜ yerleşkelerinde bulunan yeşil alan ve parkların öğrenciler ve personelin yaşam kalitesi üzerine etkileri araştırılmıştır. SDÜ Yerleşkelerinde hâlihazırda kullanılmakta olan parklar ve yeşil alanların kullanım olanakları araştırılmıştır. Personel ve öğrencilerin kullanım düzeyleri ile işlevsellik durumu belirlenmiş, donatı ve bitkisel elemanlar açısından yeterlilikleri tespit edilmiştir. SDÜ yeşil alanlarını kullanıcıların rekreatif ihtiyaçlarına ne kadar cevap verilebildiği belirlenmiş ve kullanıcılar açısından memnuniyet düzeyleri belirlenerek mevcut tablo tespit edilmiştir.

Ortaya çıkarılan mevcut durum tablosuna göre, yapılabilecek rekreasyon çalışmaları konusunda, eksik bulunan yönler tespit edilmiştir. Ayrıca İhtiyaç duyulan peyzaj tasarım uygulamalarının hayata geçirilerek yararlanma ve memnuniyet düzeylerinin artırılması doğrultusunda öneriler getirilmiştir.

Yapılan anket çalışması ve analiz sonuçlarına göre; Araştırmaya katılanlar yeşil alan ve parklarda çoğunlukla oturup dinlenmeyi tercih etmektedirler, araştırmaya katılanlar yüksek bir oranda yeşil alan ve parklardan yararlanmadıklarını belirtmiş, en fazla yararlanan grup ayda 1-15 gün yararlandığını ifade etmiştir. Yeşil alan ve parklardan memnun olanlar ve alanların bakımlarından memnun olanların oranı çalışma sonuçlarına göre daha yüksek bulunmuştur.

Araştırmaya katılanlar yerleşkelerdeki yeşil alan ve parkları ile alanlardaki donatı elemanlarını yeterli bulmadıklarını belirtmiş̧lerdir. Çalışma sonuçlarına göre, yeşil alan ve parklardaki flora çeşitliliğinin yetersiz olduğu tespit edilmiştir. Araştırmaya katılanlar tarafından alanlarda çay bahçesi ve kafeterya sayılarının artırılması istekleri bulunmaktadır. Çalışma sonuçlarına göre, yeşil alan ve parklarda en çok talep edilen tesis yürüyüş yolu olup, sırasıyla bunu süs havuzu, kuş yuvası, çeşme, tuvalet, kafe, bisiklet yolu, bank ve kitaplık takip etmektedir.

Yeşil alan ve parkların en önemli faydasının rahatlatma ve dinlendirme olduğu çalışmaya katılanlar tarafindan ifade edilmiş bunu sırasıyla doğayla yakınlaşmayı sağlama, çevreyi güzelleştirme, havayı temizleme, spor olanağı sağlama ifadeleri takip etmiştir. Araştırmaya katılanlar, yeşil alan ve parklara bisiklet yolu ile spor aletlerinin eklenmesini istemektedirler.

Araştırmaya katılanların yeşil alan ve parklarda ortalama kalış süreleri en yüksek oranla 0-2 saat olduğu belirlenmiştir. Diğer kalış süreleri sırasıyla, 2-4 saat, 4-6 saat ve 6-8 saat olarak değerlendirilmiştir. Yerleşkelerdeki yeşil alan ve parkların genellikle ilkbahar mevsiminde tercih edildiği, daha sonra tercih oranlarına göre yaz, sonbahar ve kış mevsimini tercih ettikleri tespit edilmiştir. Yeşil alan ve parklarda, altları tam gölgeli boylu ve sık ağaçların bulunması tercih edilmiş, daha sonra sırasıyla altları yarı gölgeli boylu ağaçları ve en düşük oranda altları bol güneşli boylu ve seyrek ağaçları tercih ettiklerini belirtmişlerdir.

Üniversite yerleşkelerindeki, peyzaj alanlarının eğitim çalışmalarında kullanılabilmesi için yeterli olmadığı düşünülmektedir.

Araştırmaya katılanlardan; erkeklerin kadınlara göre yeşil alan ve parklardan memnuniyet düzeylerinin daha fazla olduğu tespit edilmiştir. Araştırmaya katılanların yaş dağılımlarının verdikleri cevaplar yönünden fark oluşturmadığı belirlenmiştir. Bu alanlarda yapılan aktiviteler eğitim durumuna göre farklılık göstermektedir. Araştırmaya katılanlardan lisansüstü eğitime sahip kişiler bu alanları yürüyüş yapmak için kullanırken, lise ve lisans mezunları oturmak ve dinlenmek için kullanmaktadırlar. Araştırmaya katılanlardan bekârların yeşil alan ve parklardan memnuniyet düzeyinin daha yüksek olduğu tespit edilmiştir. Araştırmaya katılanların çalışma pozisyonları yeşil alan ve parklardan memnuniyet düzeyleri açısından farklılık göstermekte olup, işçilerin memnuniyet düzeylerinin diğer guruplardan daha fazla olduğu tespit edilmiştir. Akademisyenlerin yeşil alan ve parkları yürüyüş yapmak için kullandığı, diğerlerinin genellikle oturmak ve dinlenmek için kullandığı tespit edilmiştir.

Yapılan bu çalışma ile Süleyman Demirel Üniversitesi yeşil alan ve parklarının personel ve öğrencilerin yaşam kalitesi üzerine etkileri araştırılmış, memnuniyet düzeyleri belirlenmiş, talep ve istekleri tespit edilerek konuyla ilgili çözüm önerileri sunulmuştur. 
- Üniversite yerleşkelerinde personel ve öğrencilerin rekreasyonel taleplerinin karşılanarak, çalıştıkları ve öğrenim gördükleri mekânların daha cazip hale getirilmesi onların stres düzeylerini azaltarak, psikolojik olarak rahatlamalarını sağlayacaktır.

- Üniversite yerleşkelerinde yapılacak planlamaların, artan personel ve öğrenci sayılarına göre uzun vadeli öngörülerek yapılacak bina ve tesislerin konumlandırılmasında rekreasyonel alanların belirlenerek uygulamaların bu planlama doğrultusunda yapılması.

- Yerleşke içindeki yeşil alan ve parkların rekreasyon açısından daha cazip hale getirilerek, bu alanlardan yararlanmayan grupların alandan yararlanmalarının sağlanması.

- Alanlardan sorumlu ilgili idareler ( Yapı İşleri ve Teknik Daire Başkanlığı, Park ve Bahçeler Şube Müdürlüğü vs.) ile koordinasyonun sağlanarak, alanlardaki donatı elemanlarının( bank, pergola, aydınlatma unsurları gibi) sayılarının ve kullanışlılıklarının artııılması sağlanmalıdır.

- Alanlardaki flora çeşitliliğinin artırılması ve alandaki doğal yapıya uygun bitkisel materyallerin kullanılması sağlanmalıdır.

- Alanların daha işlevsel kullanılmasını sağlayacak, çay bahçesi ve kafeterya gibi yapıların artırılması sağlanmalıdır.

- Yeşil alan ve parklarda, yürüyüş yolu, süs havuzu, kuş yuvası, çeşme, tuvalet, bisiklet yolu gibi yapıların artırılması ve yerleşkelerde homojen bir dağılım tesis edilmesi gerekmektedir.

- Yeşil alan ve parkların faydalarıyla ilgili olarak, farkındalık oluşturacak çalışma ve etkinliklerin yapılması, konuyla ilgili olarak üniversitede yer alan topluluk ve grupların desteklenmesi sağlanmalıdır.

- Yerleşkelerde bulunan yeşil alan ve parkların sadece belirli mevsimlerde değil, bütün mevsimlerde kullanılmalarını sağlamak amacıyla çalışmalar yapılmalı, yarı açık veya kapalı rekreasyon alanları oluşturulmalıdır.

- Yeşil alan ve parklarda bitkilendirme çalışmaları esnasında görsel tasarıma önem verilmeli, temalı parklar oluşturulmalıdır.

- Yaya ve araç sirkülasyon yolları oluşturulmalı, yeşil alan ve parklara ulaşım kolaylaştırılmalıdır.

- Yerleşke içindeki yollara, her yola özgü belirleyici ve özgün ağaçlandırma çalışmaları yapılmalı ve yolların o ağaç isimleriyle isimlendirilmesi sağlanmalıdır.

- Alandaki parkları kullanan özellikle kadın kullanıcıların kendilerini güvende hissetmeleri sağlanmalı, parklar buna göre konumlandırılmalı ve gerekli aydınlatma öğeleri ile güvenlik önlemleri oluşturulmalıdır.

- Hastane bölgesinde, hasta ve hasta yakınlarını psikolojik olarak rahatlatmak, dinlenme, yürüyüş olanakları sağlamak amaciyla iyileştirme bahçeleri oluşturulmalı, çevredeki yeşil alanlar geniş çim alanlar olarak tasarlanmalı, gerekli donatı elemanları ile desteklenerek suni gölet gibi alanlar oluşturulmalıdır.

\section{Teşekkür}

$\mathrm{Bu}$ makale Süleyman Demirel Üniversitesi, Fen Bilimleri Enstitüsü'nde hazırlanmış olan Yüksek Lisans çalışmasının bir bölümünün özeti olup, anket çalışmalarına katılan Süleyman Demirel Üniversitesi personeli ve öğrencilerine teşekkür ederiz. 


\section{Kaynaklar}

1. Akdoğan, G. (1987). Doğa Düzenleme Ders Notları, Yıldız Üniversitesi, Fen Bilimleri Enstitüsü. Peyzaj Planlama, Yüksek Lisans, İstanbul.

2. Akesen, A. (1978). Türkiye'de Ulusal Parkın Açıkhava Rekreasyonu Yönünden Nitelikleri ve Sorunları (Örnek: Uludağ Ulusal Parkı), İ.Ü. Orman Fakültesi Yayınları, No: 2484/262, İstanbul.

3. Baş, T. (2005). Anket Nasıl Hazırlanır Uygulanır Değerlendirilir. Seçkin Yayıncılık, Ankara.

4. Bilgili, B.C., Gökyer, E. (2012). Urban Green Spaces System Planning-Landscape Planning. http://cdn.intechopen.com/pdfs/37556/InTech-Urban_green_space_system_planning.pdf daresinden erişildi.

5. Ceylan, A. (2007). Yaşam Kalitesinin Arttırılmasında Kentsel Yeşil Alanların Önemi Ve Kentsel Dönüşüm İle İlişkilendirilmesi, İstanbul Teknik Üniversitesi, $\square$ Fen Bilimleri Enstitüsü, Yüksek Lisans Tezi, İstanbul.

6. Ertekin, M., Corbacı, Ö.L. (2010). Üniversite Kampüslerinde Peyzaj Tasarımı(Karabük Üniversitesi Peyzaj Projesi Örneği), Kastamonu University Journal of Forestry Faculty, 10 (1), 55-67.

7. Gül, A., Küçük, V., (2001). Kentsel Açık-Yeşil Alanlar ve Isparta Kenti Örneğinde İrdelenmesi, S.D.Ü. Orman Fakültesi Dergisi, A, 2, 1302-7085, 27-48, Isparta.

8. Gül, A., Keleş, E., Uzun, Ö.F. (2016). Süleyman Demirel Üniversitesi Öğretim Elemanları ve Öğrencilerinin Yerleşke İçindeki Rekreasyonel Talep ve Eğilimleri. Süleyman Demirel Üniversitesi Mimarlık Bilimleri ve Uygulamaları Dergisi, 1: 26-43, Isparta.

9. Huang, C.Y., Carleton, B. (2003). The Relationships among Leisure Participation, Leisure Satisfaction, and Life Satisfaction of Collegestudents in Taiwan, Journal of Exercise Science and Fitness, 1(2), p.129132.

10. Karakaş, B. (1999). Üniversite Yerleşke Planlaması, Edirne Devlet Mühendislik ve Mimarlık Akademisi, Edirne.

11. Keleş, R. (1984). Kentleşme ve Kent Politikası, A.Ü. Siyasal Bilgiler Fakültesi Yayınları No: 540, Ankara.

12. Mete, B., Ağaoğlu, S.A. (2003). Ondokuz Mayıs Üniversitesi Kurupelit Kampüsü Akademik ve İdari Personelin Rekreatif Aktivitelere Katılım ve Bakış Açılarının incelenmesi", Beden Eğilimi ve Sporda Sosyal Alanlar Kongresi Bildiriler Kitabı, 5.42]-426, Ankara.

13. Müderrisoğlu, H., Uzun, S. (2004). Abant İzzet Baysal Üniversitesi Orman Fakültesi Öğrencilerinin Rekreasyonel Eğilimleri. Süleyman Demirel Üniversitesi Orman Fakültesi Dergisi. A(2):108-121.

14. Önder, S. (2003). Selçuk Üniversitesi Öğrencilerinin Eğilim Ve Taleplerinin Belirlenmesi Üzerine Bir Araştırma. Selçuk Üniversitesi Ziraat Fakültesi Dergisi 17 (32):31-38.

15. Özbilen, A. (1991). Kentiçi Açık Alanlar ve Dağılımı, Tarihi Eserler ve Gelişen Yeni Yapılaşma, Karadeniz Teknik Üniversitesi, Orman Fakültesi, Genel Yayın No:155,F.Y.N: 17, Trabzon.

16. Tolunay, A., Alkan, H., Korkmaz, M. (2004). Isparta Tarihi Ayazmana Mesireliği'nin Açıkhava Rekreasyonu Açısından Kullanıcı Özellikleri. Süleyman Demirel Üniversitesi, Fen Bilimleri Enstitüsü Dergisi, 8-1: 59-70.

17. Tunçkol H M, Çumralıgil B (2005). Selçuk Üniversitesindeki Akademik Personelin Rekreasyol Faaliyetlerinin Değerlendirilmesi. Beden Eğitimi ve Spor Bilimleri Dergisi, 7(4), 45-51.

18. Türksever, N. (2001). Türkiye'de Büyük Şehir Alanlarında Yaşam Kalitesinin Değerlendirilmesine Yönelik Bir Yöntem Denemesi, Doktora Tezi, İstanbul Teknik Üniversitesi, Fen bilimleri Enstitüsü, İstanbul.

19. Yağmur, R., Ocak, Y. (2013). Afyon Kocatepe Üniversitesi Beden Eğitimi ve Spor Yüksekokulu Ögrencileri İle Farklı Bölümlerdeki Öğrencilerin Serbest Zaman Aktivitelerinin Karşılaştırılması. Spor ve Performans Araştırmaları Dergisi, 4(1), 5-16. 
20. Yıldızcı, A.C. (1982). Kentsel Yeşil Alan Planlaması ve İstanbul Örneği, Doçentlik Tezi, İ.T.Ü. Fen Bilimleri Enstitüsü, İstanbul.

21. Yılmaz, B. (1998). Bartın Kenti Açık ve Yeşil alan Sisteminin Saptanması Üzerine Bir Araştırma, Peyzaj Yüksek Mimarlığı Tezi, Zonguldak Karaelmas Üniversitesi Fen Bilimleri Enstitüsü Peyzaj Mimarlı̆̆ı Anabilim Dalı, Bartın. 